\title{
Understanding Values of Democracy through Student Moral Movement to Achieve a Good Governance in Garut Regency
}

\author{
Jamilah Jamilah \\ Institut Pendidikan Indonesia \\ Garut, Indonesia \\ jamilah@institutpendidikan.ac.id
}

\begin{abstract}
This research is motivated by the emergence of various student movements in Garut district that occurred due to dissatisfaction with the performance of the government Garut regency. The movement takes place as a form of responsibility of an academic who has the understanding and experience of how to express opinions in public through demonstration actions. The purpose of this research is to describe, analyze, study and organize empirically about: (1) understanding of student democracy, (2) journey of moral movement student in year 2017, (3) student movement in realizing good governance and (4) implementation of the student movement in the implementation of good governance. The approach used is qualitative with analytical descriptive method. Field data were collected through interviews, observation and documentation. Data were analyzed through the stages: (1) Data collection; (2) data reduction; (3) Presentation of data; (4) Conclusion or verification. The results of this study show: Firstly, informants generally understand the values of democracy in the study of good governance, but their understanding based on the circumstances in accordance with their respective perspectives. Second. The result of the study of students moral movement movement in Garut regency, clearly visible throughout the year 2017 by addressing various bureaucratic phenomena, ranging from promises during the regent campaign, accountability, transparency, public service, bureaucratic reform, law supremacy, to public policy issues Garut regency. Third, the moral movement of students in Garut regency in realizing a good governance implemented by aspiring freedom of thought, opinion and freedom to participate both orally, and writing. Fourth, the implementation of student moral movement in Garut regency can provide better development with marked freedom of expression both oral and written. The recommendations of this research are: (1) For the academic community, students must always perform their moral movements based on the values, norms and culture of their nation, as well as the regulation of the local government that regulates it; lecturer, should provide deep insight in relation to democratic values especially about student movement; (2) For policymakers, it should facilitate and provide solutions to the students moral movements to proceed as they should, (3) future researchers, can examine more deeply about whether the movement moral students as a moral movement or political movement.
\end{abstract}

Keywords-democracy; good governance; .student moral movement

\section{INTRODUCTION}

Students as agents of change (agent of change), is a social group that has a high degree of independence. When associated with the social component, students cannot be separated from the dialectical structures that exist, whether social, economic, and political. They as actors (actors, agents) social should respond to changes that occur. But at the same time, the response must be limited by the historical and social background that has occurred and lasted before. It implies, the existence of students must historically be a group that is well impressed by society, so as to give birth to a new resurrection history for the expected new social order, so it can be regarded as an impressive young man [1].

The student movement that marked the occurrence of political reform in the Indonesian system of government contributed greatly to the political arena in the land of the country. Although today Indonesian politics is still in positive negative shadows. However, students are considered an inalienable part of their work to build a good and democratic government. They can be categorized into groups that want radical and fundamental change, a gradual change to avoid the fluctuations that could endanger national life, and those who oppose any change to competitive democracy because they judge it to be inconsistent with Indonesian cultural values [2].

This is in line with the mission of Civic Education in Higher Education, as described in the Decree of the Director General of Higher Education No. 43 / DITI / Kep / 2006 that Civic Education can help students consolidate their personality to be consistently able to realize the basic values of religion and culture, the sense of nationality and love of the homeland throughout life in mastering, applying and developing the science, technology and art it possesses with a sense of responsibility. The relevance of the role of the student in his moral movement with Civic Education lies in the active participation he undertakes in accordance with the nature of Civic Education itself that Civic Education is designed to prepare young citizens, in order to play an active role in their community [3].

In addition, according to Winataputra, Citizenship Education in one of its status states that, "Civic Education as a conceptual framework in the form of individual thinking" [4]. 
It explains that with the planting of values and understanding of democracy material that is learned through Civic Education, students can run their existence as a reformer agent in order to criticize the government through the way it is considered effective i.e. the demonstration action. Although, in the next explanation Winataputra explained that the education framework Citizenship is still not synergistic. Another opinion explains that "Civic Education is both as the main vehicle as well as the essence of education for democracy". Even still according to CICED, "Democratic Ideals, Values, and Practices in a Civil Society and their implication on Civic Education". Thus, the more clearly the position of Citizenship Education as a vehicle in shaping the experience of citizens who provide education for democracy.

However, the challenges facing students in the current reform era are very heavy. This is because many irregularities are perpetrated by politicians who attempt to deflect the reformation of the pre-reform era [1]. Under such circumstances, student movements as revealed in Hassie research are a form of high awareness of the plight of a nation of uncertainty [5]. From another angle, the direction of the student movement is still a question of whether the political movement or the moral movement [6]. However, for students the moral movement is much more valuable because it will allow students to see the issues of politics more clearly or avoid vested interests.

One of the goals of the reform movement in Indonesia is the change of government system from authoritarian to democracy. This is because almost every country in the world believes in democracy as "the undisputed benchmark of political legitimacy." The belief that the will of the people is the main basis of the government's authority becomes the basis for the robustness of the democratic political system. The statement is in line with the 1945 Constitution of the State of the Republic of Indonesia, Article 28 which reads "Freedom of association and assembly, issue of thought with oral and written and so on is stipulated by law". Further reinforced by the Law of the Republic of Indonesia Number 39 Year 1999 about Human Rights Article 25 which reads "Everyone has the right to express opinions in public, including the right to strike in accordance with the provisions of legislation", and the Law of the Republic of Indonesia No. 9/1998 on Freedom of Expression of Public Opinion contained in Article 1 which reads "Freedom of expression is the right of every citizen to express his thoughts orally, in writing, and so on freely and responsibly in accordance with the provisions of laws and regulations apply ". The above rule is a protection against student moral movement found in the homeland.

In doing the movement, the students combine the two heads, the first head is the mass action and the second head is the intellectual action [7]. Student social movement is one form of statement of the will of the people who should be respected as a democratic ideology, meaning the voice of freedom that coveted society in democratic life. There are 10 pillars for the learning of democracy, namely: "the ten pillars of Indonesian constitutional democracy: belief in God, Human Rights, People Souverignity, People Intelligence, Separation of State Power, Local Autonomy, Rule of Law, Independent Court, People Prosperity, and Social Justice need Revitalizing" [8].
As one of the democratic manifestations movement, the student movement becomes one of the strengths of control over the performance of government to fit the aspirations of the people. Student movement today is a movement of mass and intellectual action. With this movement, the values of democracy or freedom of expression are open to every individual, which in the end is expected to co-exist together to facilitate the growth and development of a democratic Indonesian civil society.

Students become the foundation of various parties. They are often referred to as the hope of the nation, the hope of the country, the hopes of society, the hopes of society, the hope of the family and even the hope of the world. But along with student identity, there are roles to be performed as a logical consequence and the automatic consequence of that identity. The various terms require the identity of the student to do something that should be done, there is hope behind the various titles and nicknames for students. There are consequences of student identity, including the academic aspect, which demands the role of the student only one, that is learning; the organizational aspect that explains that not everything can be learned in the classroom and the laboratory. There is still much to learn outside the classroom, as in organizations; and sociopolitical aspects that illustrate that the student is a part of the people, even he is the people themselves. So he is required to see, to know, to realize and feel the real condition of his society which today is being overwhelmed by multidimensional crisis [9].

Student movement in Indonesia is a student activity which is done to improve the skills, intellect and leadership ability of the activists involved in it. This can happen if the actions of the students are based on spirit of statesmanship, have intellectual orientation, and as agent of change (agent of change) [1]. However, if the student movement is out of the way, then there are some errors in the movement of change. It can be seen from student collectivity seem chaotic and offer less solution of continuous change. This situation occurs because the student movement is less able to spawn good cadre, problem management and action that is not touching the grass root, and polarization of ideology and principle of student movement.

In fact, if the situation continues to grow among students, then the student movement to perform again in great strength makes their bargaining power decline. This happens because the nuance of protest is more directed to relatively narrow space, the issue brought by the student movement tends to be partial and nuanced to the interest of certain groups (primordial), the repressive action of the Police officers increasingly collects the desire to collect the action down the street, and their roles crushed by politicians who emphasize the interests of particular political groups and parties [10].

One of the agenda often done by students is related to bureaucracy and government reform, both at central and regional level, especially after the rolling of regional autonomy. After becoming mainstreaming issue, the concept of governance of view of the assessment that produces various understandings. The main principles that can give a description of public administration that characterizes good governance is 
accountability, transparency, openness and law enforcement $[11,12,13]$.

In implementing good governance cannot be separated from the leadership carried in a government. This can happen because good governance can be achieved if the public bureaucracy is able to develop its leadership toward a reliable leader character such as visionary, unifier, empowerment, emotional-ratio control (RE), and integrity [14]. Good governance is coveted both by the central and regional, is an important agenda for students in carrying out the action.

In the political practice of democratic statehood, good governance can be indicated by ensuring public services and people's basic rights, and exercising a power based on a sense of responsibility for the interests of the people. However, the government in exercising its power needs to be limited, because power is essentially the mandate of the people. One of the issues that develop today is the movement of students in Garut regency who do not cease to expect reform of bureaucracy and good governance will soon be realized. After the fall of government under Regent Agus Supriadi who stumbled corruption case, Garut name into the national media spotlight. Several years ago, exactly January 23, 2009 Garut community has a new leader. Regent and Vice Regent of Garut the first in the history of Garut Regency directly elected by the people. Surely the people of Garut have great hopes for new leaders who carried from independent candidates or Independent and identify themselves as a representation of the community of HM Fikri and Dicky Chandra.

However, the political dynamics that so deeply enveloped the new government is still not in accordance with the will of the people. This of course ignites the responsibility of students to perform its actions for the welfare of Garut regency community. The situation was revealed in an interview conducted by researchers at pre-research (July 15, 2012) that students consider that the new government has not run the agreed social and moral contract between the elected government and the society, the demands of students to implement bureaucratic reform have not been well realized. With various circumstances and changes, the decisive situation when the election of Agus Hamdani finally became the culmination of a long discourse on the polemic whether or not the position of Vice Regent of Garut to be filled after Dicky Chandra resigned as Vice Regent of Garut.

Garut that never separated from the student movement brings its own characteristics in the democracy, where the rampant demonstration will continue the voice of the people in viewing the implementation of local government Garut regency to be a clean district and the community. Referring to the above exposure the author is interested to examine the problem with the title: "Understanding of Values Democracy through Student Movement to realize Good Governance in Garut"

\section{A. Problem Research Formulation}

The focus of the research problem that will be studied in this research, namely: "How to strengthen the values of democracy through the movement of inner students in Garut regency?"
Based on the above research problems, it can be formulated research questions as follows:

- How to understand the values of student democracy in Garut regency?

- How is the moral movement of students in the District of Garut?

- How does the student movement impact on the implementation of good governance?

\section{B. Research Objective}

The purpose of this research is to describe, analyze, review and organize empirically about:

- Understanding the values of student democracy in Garut regency.

- Student Moral Movement in Garut District.

- Impact of students' moral movements on the implementation of good governance.

\section{THEORETICAL STUDIES}

Etymologically, democracy comes from the Greek word meaning demos, and cratos or cratien meaning government or power. So in language, demos-cratien or demos-cratos means people's government or people's power. The word has connotations (1) a government elected by the people, (2) a government by ordinary people, (3) a (government by the poor) or a small people. However, what is important for a democracy is not just who chooses the leader, but also the way he leads. For if the way of leading the country is incorrect, both because of the low quality and moral commitment of the leaders themselves, as well as the unfavorable culture of the local people, democracy is simply the polishing of tyranny by the nobility to tyranny by the lower society.

Democracy as a system has been made an alternative in various social and state activities in several countries. Mahfud $\mathrm{MD}$ argues that there are two reasons for the democracy as a system of society and state [15]. Firstly almost every country in the world has made democracy a fundamental principle; secondly, democracy as the principle of state has essentially given direction for the role of society to organize the state as its highest organization. Therefore, knowledge and understanding of citizens about democracy are needed.

The concept of democracy born out of ancient Greece practiced in the life of the state between 4th century BC - 6th century $\mathrm{AD}$ The democracy that occurred at the time was (direct democracy), meaning the people's right to make political decisions run directly by all citizens or citizens. Thus, democracy can be based on the distribution of the will of the people in a direct way, namely the understanding of democracy which includes every citizen in the deliberations to determine the general policy and the law and indirectly that is understood democracy implemented through a representative system is usually done in the General Elections [16].

In addition, Sklar in the ICCE UIN Jakarta Team proposed five styles or models of democracy, namely liberal democracy, 
guided democracy, social democracy, democratic participation and constitutional democracy [15].

- Liberal Democracy, i.e. a government restricted by law and free elections held in a steady time. Many African countries apply this model, but few survive.

- Guided Democracy. The leaders believe that all their actions are trusted by the people but refuse the competing elections as vehicles to occupy power.

- Social democracy is a democracy that cares about social justice and egalitarianism for the requirement to gain political trust.

- Participation democracy, which emphasizes the mutual relationship between the ruler and the ruled.

- Consociation democracy, which emphasizes special protection, for cultural groups that emphasize close cooperation among the elite representing the cultural part of the ultimate community.

In terminologically, democracy can be defined as the government of the people, by the people and for the people (government of the peoples, by the peoples and for the peoples. Thus, in general democracy can be interpreted as the process of fostering sovereignty as much as possible in the hands of the people.

In the tradition of "medieval theory" it means that democracy is "...a foundation for the exercise of power, leaving the supreme power in the hands of the people" or a foundation for the exercise of supreme power in the hands of the people [17]. In contemporary doctrine of democracy is seen as "... the most genuinely popular form of government", or the concept of a republic as a pure form of peoples government. While Torres describes democracy in 2 aspects: formal democracy which refers to the system of government and substantive democracy consisting of 4 forms of democracy namely; protective democracy, developmental democracy, equilibrium democracy and participatory which all basically involve domination and sovereignty in the hands of the people [18].

Based on the concept of democracy, it is clear that the main subject of democracy is a citizen so that one's citizenship determines the process of democratization in the life of society and state.

Literally, the word democracy comes from the Greek word "demos" (people) and "kratia" (rule or authority) and means rule by the people or government by and for the majority. Democracy can thus be contrasted with rule by a single individual (as in monarchy or tyranny) or rule by a few (e.g. aristocracy or oligarchy) [19].

Lane and Errsson, describe that democracy is an institutional arrangement for arriving at political decisions in which individuals acquire power to decide by means of a competitive struggle for the people's vote.

Further, Lane and Errson illustrate that democracy if may be defined as a way of life, addressing willingness to compromise, tolerance, and a willingness to listen to and be influenced by arguments [20]. While Levin compares two dimensions of democracy: politics and a participative process. By "formal politics" he means voting, election, and political parties. With respect to formal politics, i.e. [21].

Basically democracy in the system of government is the government's efforts in realizing and guaranteeing the elements of freedom, justice and equality before the law and legislation concerning the individual freedoms of society as citizens or citizens of the world who are able to express themselves by upholding human values.

In the order of democracy applied a system of government of a country where all citizens have the right, obligation, position and good power in running their lives and in participating in the power of the state, the people have the right to participate in running the state or oversee the state power, either directly for example through public spheres or through elected representatives in a fair and honest manner with governments run solely for the benefit of the people. So that the system of government in the country comes from the people, run by the people for the people (from the people, by the people, for the people). Therefore the system of democratic government is used as opposed to the system of tyrannical government, autocracy, despotism, totalitarianism, aristocracy, oligarchy and theocracy. In terms of democratic methods is a form of institutional resolution to achieve political decisions in which individuals gain power to decide by means of a competitive struggle over the voice of the people [22].

While Dahl, explains that democracy is a political system where each member views each other as equally politically, equally sovereign, and has all the abilities, resources and institutions they need to govern themselves [19]. The democratic system is characterized by a (responsive) attitude to the preference of its citizens. Such responsiveness suggests that citizens should have the opportunity to: (1) formulate their preferences, (2) notify the preferences of other citizens and the government through individual or collective action, (3) consider the entry of the references into the rules of government.

\section{RESEARCH METHODS}

In this study, researchers used descriptive analytical methods with a qualitative approach. It is used to gain an indepth understanding of the subject and object of the research undertaken. According to Cresswell qualitative research is a process of inquiry to understand social or human problems, based on the creation of a complete holistic picture formed in words, reporting informant views in detail, and arranged in a natural setting [23].

Research on student moral movement is more likely to be done with a qualitative approach. This is because the process of the occurrence of the movement is natural that appears in man in order to fight for the rights of self and the people who are around him. In addition, this study was not designed to test the hypothesis, but only describes the tendency of symbolic phenomena and the reflection of what is happening from the situation so that this study uses a qualitative approach. Cresswel explains that in formulating the identification of problems in qualitative research, the researcher should 
emphasize the exploration of the issues raised by explaining in depth the subject (the main concept under study) [23]. While in quantitative research, description or explanation of the relationship between the variables studied. In formulating the identification of problems in qualitative research, one of the things that influence it is the qualitative research model that is used because each model has its own characteristics and objectives which influence the discussion in identifying the problems.

Furthermore, Cresswel asserts that in qualitative research, theoretical or literary involvement is limited to research problems, but does not serve as an identification of the research direction, research objectives, or research questions raised [23].

Data collection techniques used to collect data and information about aspects of student movement in realizing good governance is very dependent on the activities developed in this study. The implementation procedure is tailored to the condition of the data source and the location in which the respondent performs its duties. In particular it can be stated that this research uses data collection techniques such as: observation, interview, documentation and literature study.

- Observation is the collection of data by means of direct observations, including concentration of attention to an object by using all the senses. Observation means to observe and follow [24]. Observe and follow in the sense of carefully observing and systematically targeting the intended behavior. In this case the authors observe, pay attention and follow about the experience of democratic learning, especially related to student moral movement in Garut regency.

- Interviews are dialogs by which the interviewer gets information from. An interview is interactional because there is an exchanging, or sharing of roles, responsibilities, feelings, beliefs, motives, and information [24]. If one person does all of the talking, a speech to an audience, of one, not an interview, is taking place. "The author performs interview according to the interview material guidelines that have been prepared. This interview intends to extract data and information from the research sample in accordance with the proposed problem.

- Documentation aims to supplement the data. Documentary study is one method of collecting qualitative data by viewing or analyzing documents created by the subject himself or by others about the subject. Documentation study is one way qualitative researchers can do to get a picture from the point of view of the subject through a written medium and other documents written or made directly by the subject concerned. In this connection the authors collected some documentation data related to the research [24].

- Literature study is a reference search theory relevant with the problems found, such references can be, books, journals, research reports articles and internet sites. Output from this literature study is as material in taking data theoretically that has to do with writing this dissertation.

\section{RESUlt OF THE STUDY}

\section{A. Understanding Student Democracy Values in Good Governance Review in Garut District}

From the exposure that has been expressed can be expressed about the understanding of democracy in an effort to realize good governance. In general, the understanding of students, lecturers as well as educational practitioners and some government officials, can be presented descriptively that they understand the democracy within the framework of government service in managing its government in line with the spirit of democracy based on the concept of good governance

\section{B. Garut Moral Students Movement in Realizing Good Governance}

As a movement (movement organization) student movement is a movement that seeks to mobilize or mobilize the students and society collectively. The movement is done to realize the political awareness of each individual society in order to oppose all the oppression that is done by the state. Thus, the student movement is a movement to fight the country's hegemony. In to achieve success requires a strong and united movement as well as radical ideas, ideas and political actions. Strictly speaking, the concept of social movement built by students is a movement that has a form of behavior as well as its own culture.

\section{Implementation of Student Moral Movement on Good Governance Implementation}

The role of the student movement towards the development of democracy in the community has a high significance, in the era of democratic tension reform it again becomes a great force in building this nation. Based on the results of interviews about the implementation of the student movement towards the development of democracy in an effort to realize good governance, each informant gives a different explanation, but has almost the same meaning.

If traced back the results of interviews with informants, it can be argued that the role of students can provide feedback that the student movement is very important in the effort to act as a control of power for the government to exercise its power does not hurt the people he leads

\section{CONCLusion AND Suggestions}

\section{A. Conclusion}

Understanding the values of student democracy in Garut Regency influenced the understanding of individuals who started with the vehicle Citizenship Education as forming the experience of citizens who provide education for democracy and the circumstances and conditions of his government as contextual conditions are interpreted in accordance with their respective perspectives. In general, the view of democracy leads to a mechanism of government in creating prosperity. The relationship of democracy with good governance is emphasized by one of the members of Parliament Garut Regency that the democracy emphasizes the government based 
on people's sovereignty and good governance emphasize management techniques. Thus, the understanding of democracy in the study of good governance in Garut regency is the implementation of local government that involves the aspirations of the people in order to influence the decision / policy making in creating a good government order (in the sense formal democracy).

The values of student democracy in Garut regency in realizing the good governance implemented by aspiring freedom of thought, opinion and freedom to participate both orally and in writing in order to realize the state and good government by way of action (demonstration). The demonstration occurred because of the concerns of Garut Regency students about the government as a public servant who has tarnished his duties and responsibilities. So with the demonstration, it is expected that good governance in Garut regency can be realized.

Implementation of student moral movement towards the implementation of good governance in Garut district that can provide a better development of democracy with a marked freedom and guarantee of freedom of expression both oral and written. It began with the reform movement that took place in 1998 as a sign of the opening of the gate of people's democracy. In addition, the impact that can be given from the student's moral movement that can be a control of power for Garut regency government in exercising its power does not misuse the community of Garut.

\section{B. Suggestions}

Based on the findings of the study researchers can provide some recommendations as follows:

\section{1) For the academic community}

- Students, the student's moral movement should always be done based on the values, norms and culture of the nation that exist, so that the movement carried not out of the goal to build democratic values in accordance with the philosophy of Indonesia.

- Lecturer, always provide insight into the conception of moral movement that is truly moral in an effort to realize good governance and good democratic climate.

- Educational practitioners, always provide direction and attention that the realization of democratic climate and governance requires the carrying capacity of every element of the nation, so that in everyday life always provide intelligence for elements in society.

2) For policy makers

Students' moral movements should be facilitated and looked for solutions so that in every action, students can do it responsibly without causing anarchism.

\section{3) The next researcher}

It is possible to conduct more in-depth research in every student movement whether as a moral movement or a political movement. It needs to be disclosed in order to answer the people's doubts about the demonstration conducted by the students because it is considered not to voice the aspirations of the people especially in the state of anarchy. In addition, it can also be studied, to what extent the influence of student participation in campus organization can affect his academic achievement.

\section{REFERENCES}

[1] D. Rudianto, Gerakan Mahasiswa: Dalam Prespektif Perubahan Politik Nasional, Jakarta: Golden Terayon Press, 2010.

[2] D.F. Anwar, Konflik Kekerasan Internal-Tinjauan Sejarah-Ekonomi Politik dan Kebijakan Asia Pasifik, Jakarta: British Council, 2009.

[3] J.J. Cogan, Developing the Civic Society: The Role of Civic Education, Bandung: CICED, 1999

[4] U.S. Winataputra, "Jatidiri Pendidikan Kewarganegaraan Sebagai Wahana Sistemik Pendidikan Demokrasi: Suatu Kajian Konseptual Dalam Konteks Pendidikan IPS”, (Disertasi PPS UPI), unpublished.

[5] J. Hassie, "Anarkisme Demonstrasi Mahasiswa: Studi Kasus pada Universitas Islam Negeri Alaudin Makasar", Jurnal Studi pemerintahan, vol. 3, no. 1, pp. 45-46, 2012.

[6] S. Usman, "Arah Gerakan Mahasiswa: Gerakan Polisi ataukah Gerakan Politik”, Jurnal Ilmu Sosial dan Ilmu Politik, vol. 3, no. 2, pp. 146-163, 1999.

[7] J.A. Denny, Gerakan Mahasiswa dan Politik Kaum Muda Era 80- an, Yogyakarta: LKIS, 2006.

[8] A. Sanusi, Memberdayakan Masyarakat dalam Pelaksanaan 10 Pilar Demokrasi, Bandung: Makalah, 1998.

[9] I. Kusumah, Risalah Pergerakan Mahasiswa, Bandung: INDIDEC PRESS

[10] A. Matulessy, Mahasiswa dan Gerakan Sosial, Jogjakarta: Srikandi, 2005.

[11] A. Dwiyanto, "Governance Practices and Regional Autonomy: Evidences from Governance and Decentralization Survey (GDS)", Partnership for Governance Refrom in Indonesia and Word Bank, Yogyakarta, 2003.

[12] Syakrani, and Syahriani, Implementasi Otonomi Daerah dalam Perspektif Good Governance, Yogyakarta: Pustaka Pelajar, 2009.

[13] Sedarmayanti, Good Governance (Kepemerintahan yang Baik) Membangun Sistem manajemen Kinerja Guna meningkatkan Produktivitas menuju Good Governance, Bandung: Mandar Maju, 2004.

[14] A.T. Sulistiyani, Memahami Good Governance Dalam Perspektif Sumber Daya Manusia, Yogyakarta: Gaya Media, 2004.

[15] Tim ICCE UIN Jakarta, Pendidikan Kewarganegaraan. (Civic Society), Demokrasi, HAM dan Masyarakat Madani, Jakarta: UIN, 2003

[16] Winarno, Paradigma Baru Pendidikan Kewarganegaraan, Panduan Kuliah di Perguruan Tinggi, Jakarta: Bumi Aksara, 2007

[17] U. Winataputra, and D. Budimansyah, Civic Education: Konteks, Landasan, Bahan Ajar dan Kultur Kelas, Bandung: UPI, 2007.

[18] A.C. Torres, Democracy Education and Multiculturalism: Dilemmas of Citizenship in a Global World, Lahman, Maryland: rowman and Littlefield, 1998.

[19] R.A. Dahl, On Democracy, New Haven: Yale University Press, $1998 .$.

[20] J.E. Lane, and S. Errisson, Democracy: A Comparative Approach, London, 2003.

[21] B. Levin, "The Educational Requirement for Democracy", Curriculum Inquiry, vol. 28, no. 1, 1998 .

[22] J. Schumpeter, Capitalism, Socialism and Democracy; reprint, London: Allenand Unwin, 1942.

[23] J. Creswell, Educational Research, Planning, Conducting, and Evaluating Quantitative and Qualitative Research, Pearson Education, Inc upper Saddle River, New Jersey, 2008.

[24] H. Heridiansyah, Metodologi Penelitian Kualitatif, Jakarta: Salemba Humanika, 2010. 